\title{
Pengaruh Pemberian Jahe, Kunyit dan Salam Terhadap Kadar Asam Urat dan Glukosa Darah pada Bebek
}

\section{The Influence of the Provision of Ginger, Turmeric and Salam Leaf to the Level of Uric Acid and Blood Glucose on Duck}

\author{
M. Sulistyoningsih*, R. Rakhmawati dan A. A. Septiyanto \\ Universitas PGRI Semarang \\ *E-mail: meisulis@yahoo.co.id \\ (Diterima: 11 November 2017; Disetujui: 31 Februari 2018)
}

\begin{abstract}
ABSTRAK
Penelitian ini bertujuan untuk mengetahui pengaruh pemberian tambahan herbal jahe, kunyit dan salam untuk menurunkan kadar asam urat dan glukosa darah pada bebek. DOD bebek subyek unsex 100 ekor. Perlakuan pada penelitian ini adalah P0 (pakan kontrol), P1 (pakan + jahe 2\%), P2 (pakan + daun salam 3\%) dan P3 (pakan + kunyit 0,2\%) dengan empat ulangan. Penelitian ini menggunakan rancangan percobaan Rancangan Acak Lengkap (RAL). Data dianalisis dengan ANOVA dilanjutkan dengan uji Duncan jika berbeda nyata antar perlakuan. Hasil penelitian pemberian tambahan herbal jahe, kunyit dan salam tidak memberikan pengaruh $(\mathrm{P}>0,05)$ terhadap kadar asam urat dan glukosa darah.
\end{abstract}

Kata kunci: asam urat, daun salam, glukosa darah, jahe, kunyit

\section{ABSTRACT}

The aim of this study was to determine the influence of additional herbs ginger, turmeric and salam leaf to decrease levels of uric acid and blood glucose in duck. The dod duck unsex 100 tail.Treatment of research is $P 0$ (feed) control, P1 (feed + ginger $2 \%$ ), P2 (feed + leaf as regards $3 \%$ ) and P3 (feed + turmeric $0,2 \%)$ with four test. This research using the experiment random design complete (RCD), the experiment analyzed by anova followed by Duncan test if any significant effect among treatments. The results showed that herbs ginger, saffron and peace levels there did not affect of on uric acid and blood glucose.

Keywords: blood glucose, ginger, turmeric, salam leaf, uric acid

\section{PENDAHULUAN}

Jumlah penduduk yang meningkat serta pola pikir masyarakat semakin berkembang tentang pentingnya pangan bergizi menyebabkan kebutuhan protein hewani meningkat. Kebutuhan masyarakat akan protein hewani meningkat menyebabkan konsumsi daging sebagai sumber protein meningkat. Daging bebek merupakan salah satu daging unggas yang di konsumsi oleh masyarakat Indonesia (Arum et al., 2014).

Permintaan daging bebek oleh masyarakat saat ini cenderung semakin meningkat. Peningkatan minat konsumen terhadap daging bebek adalah salah satu penyebabnya. Indikator kenaikan minat konsumen adalah semakin banyaknya warung pinggir jalan, rumah makan, katering, hingga restoran yang menyediakan menu daging bebek (Lembong et al., 2015).

Pemeliharaan bebek mempunyai masalah utama yaitu pada kebutuhan pakannya. Bebek memiliki sifat yaitu nafsu makan yang sangat tinggi sehingga diperlukan pendekatan melalui penelitian bidang teknologi pakan/nutrisi untuk menjawab permasalahan tersebut. Pemberian pakan akan mempengaruhi kesehatan bebek. Ganguan kesehatan yang dapat terjadi pada 
bebek adalah kadar asam urat dan glukosa dalam darah.

Asam urat merupakan produk akhir metabolisme purin yang berasal dari metabolisme dalam tubuh/ faktor endogen (genetik) dan berasal dari luar tubuh/ faktor eksogen (sumber makanan). Tubuh menyediakan $85 \%$ senyawa purin untuk kebutuhan setiap hari, hal ini berarti bahwa kebutuhan purin dari makanan hanya sekitar $15 \%$. Makanan yang mengandung zat purin yang tinggi akan diubah menjadi asam urat (Lina dan Setiyono 2014).

Glukosa (kadar gula darah), suatu gula monosakarida, karbohidrat terpenting yang digunakan sebagai sumber tenaga utama dalam tubuh. Glukosa merupakan prekursor untuk sintesis semua karbohidrat lain di dalam tubuh seperti glikogen, ribose dan deoxiribose dalam asam nukleat, galaktosa dalam laktosa susu, dalam glikolipid, dan dalam glikoprotein dan proteoglikan.

Pemberian bahan herbal tambahan menjadi salah satu cara yang dapat dilaksanakan. Bahan herbal tambahan tersebut dapat berupa jahe, kunyit dan salam. Pakanpakan herbal tersebut dimaksudkan untuk mampu mengurangi risiko ganguan kesehatan pada bebek.

Jahe mengandung gingerol dapat meningkatkan penyerapan glukosa ke sel otot bebas, dan kadar gula dalam darah menjadi stabil. Akibatnya tubuh dapat mengeluarkan insulin dan penyerapan glukosa dengan baik, sehingga dapat mencegah seseorang dari penyakit diabetes (Setyaji et al., 2016).

Curcumin sebagai bahan aktif kunyit memiliki aktivitas biologis yang luas, seperti antiinflamasi, antidiabetes, antikarsinogenik, antioksidan, antikoagulan, antibakteri, antihipertensi, dan antidislipidemia. Curcumin sebagai antidiabetes menurunkan kadar glukosa darah yang diinduksi aloksan. Curcumin pada dosis rendah dapat mencegah terjadinya katarak yang disebabkan galaktosa dan menurunkan glikasi berat pada penderita diabetes mellitus (Setiawan, 2011).
Kandungan daun salam salah satunya adalah senyawa golongan flavonoid. Golongan senyawa ini, terutama yang berada dalam bentuk glikosidanya mempunyai gugus-gugus gula. Glikosida flavonoid yang terkandung dalam daun salam tersebut bertindak sebagai penangkap radikal hidroksil seperti halnya amygdalin, sehingga dapat mencegah aksi diabetogenik dari aloksan (Studiawan, 2005).

Senyawa- senyawa seperti minyak atsiri, tannin, dan flavonoid yang banyak terdapat dalam daunnya. Kandungan dalam daun salam tersebut yang dapat menurunkan kadar asam urat dengan jalan menghambat kerja ezim xantin oksidase sehingga dapat menghambat pembentukan asam urat (Yankusuma, 2016).

Penggunaan pakan tambahan berupa jahe, kunyit dan salam, bedasarkan permasalahan di atas menjadi titik awal dilakukannya penelitian tentang "Pengaruh Pemberian Tambahan Herbal Jahe, Kunyit dan Salam Terhadap Kadar Asam Urat dan Glukosa Darah pada Bebek".

Penelitian ini bertujuan untuk mengkaji pengaruh pemberian pakan tambahan herbal terhadap kadar asam urat dan glukosa darah pada bebek.

\section{METODE}

Penelitian ini dilaksanakan pada lokasi yang berada di perumahan Plamongan Indah, Bambu Asri. Penelitian ini dilaksanakan pada 20 juni sampai dengan tanggal 18 juli 2016.

Subyek dalam penelitian ini adalah DOD dengan 4 perlakuan dan $4 \mathrm{x}$ ulangan. Jumlah bebek 100 ekor dengan kriteria jenis kelamin "unsex" pada pemeliharaan insentif menggunakan kandang beralaskan panggung yang berjumlah 4 plot kandang. kandang liter yang beralaskan campuran sekam, kapur dan pasir.

Bahan yang digunakan adalah bebek (DOD), vitamin, pakan komersil, jahe (2\%), kunyit $(0,2 \%)$, salam (3\%), vaksin, sekam. Alat yang digunakan adalah kandang, tempat 


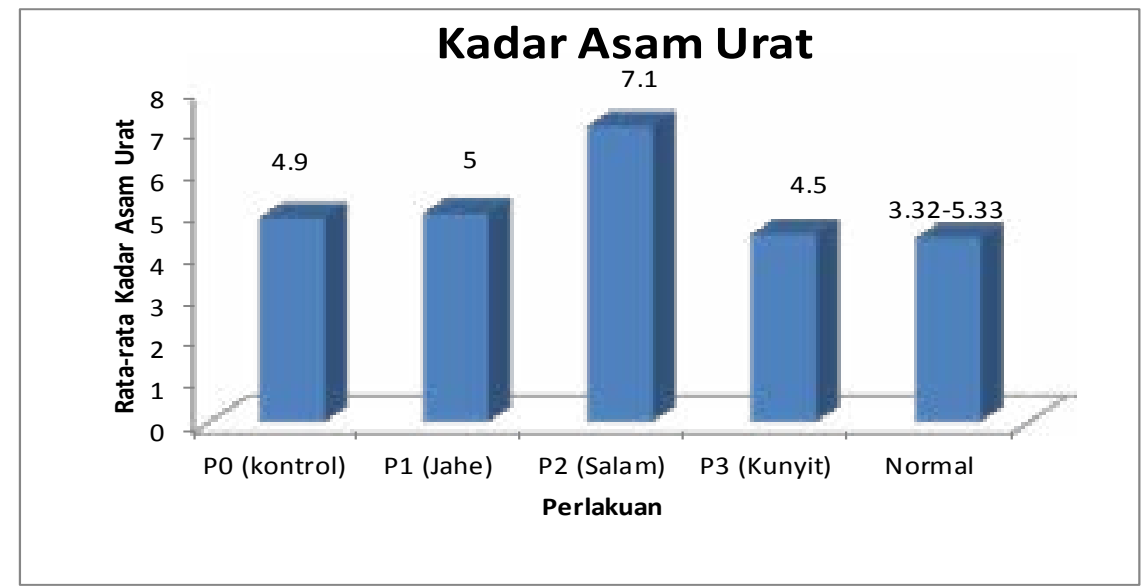

Gambar 1. Histogram Pengaruh Pemberian Tambahan Herbal Jahe, Kunyit dan Salam Terhadap Kadar Asam Urat pada Bebek.

pakan, tempat minum, sendok pakan, ember besar, thermometer, tong air, thermostat dan lampu.

Penelitian diawali dengan pembuatan kandang bebek. Pengolahan pakan organik dengan tambahan herbal berupa jahe, kunyit dan salam dengan cara membersihkan, memotongnya dalam bentuk kecil, penjemuran, menumbuknya hingga terbentuk serbuk yang tidak terlalu halus. DOD sebelum diberikan perlakuan akan dipelihara selama 10 hari terlebih dahulu. Setelah DOD berumur 10 hari maka DOD dipindahkan ke dalam kandang untuk di berikan perlakuan.

Perlakuan penelitian ini terdiri dari $\mathrm{P} 0=$ kontrol, $\mathrm{P} 1=$ tanbahan jahe $2 \%, \mathrm{P} 2=$ tambahan salam 3\% dan P3 = tambahan kunyit $0,2 \%$. Parameter penelitian yang diukur dalam penelitian ini adalah 1). Asam urat, dan 2). Glukosa darah. Pengambilan data dilakukan pada akhir minggu keenam. Analisis akhir dengan ANOVA dengan taraf signifikansi $5 \%$, bila ada pengaruh dilanjutkan dengan uji Duncan.

\section{HASIL DAN PEMBAHASAN}

\section{Asam Urat}

Hasil penelitian ini rerata kadar asam urat tertinggi adalah $7,1 \mathrm{mg} / \mathrm{dl}$ pada perlakuan tambahan herbal jahe. Sedangkan kadar asam urat terendah adalah $4,5 \mathrm{mg} / \mathrm{dl}$ pada perlakuan tambahan herbal kunyit. Penelitin ini tidak ada pengaruh pemberian tambahan herbal terhadap kadar asam urat $(\mathrm{P}>0,05)$.

Kadar asam urat pada penelitian ini berkisar 4,5-7,1 mg/dL. Kadar asam urat normal pada unggas adalah $5.33 \mathrm{mg} / \mathrm{dL}$ (Singh et al., 2013). Menurut Malkinson (2007) kadar asam urat pada bebek sehat adalah $3,32 \mathrm{mg} /$ dL. Perlakuan tambahan salam memberikan hasil yang melebihi kadar normal asam urat pada bebek dibandingkan perlakuan lainnya yang masih dalam kadar normal. Rata-rata yang didapatkan apabila U3 di hilangkan dengan menjumlahkan ketiga ulangan adalah $5,56 \mathrm{mg} / \mathrm{dl}$ yang berarti mendekati kadar normal pada bebek.

Perlakuan P1 (jahe) memberikan hasil rataan normal kandungan asam urat. Flavonoid pada jahe mampu mengurangi mengurangi kadar asam urat tanpa efek, flavonoid akan mempengaruhi metabolit biologis pada hewan normal dan mencegah stres oksidatif (Al-Azzawie, 2015). Xanthine oxidase menghasilkan asam urat dan oksidan yang merupakan enzim kunci dalam kerusakan jaringan. Enzim ini mengubah hypoxanthine dan xanthine menjadi asam urat. Flavonoid dan telah dilaporkan memiliki aktivitas penghambatan oksidase xanthine.

Perlakuan P2 (salam) memberikan hasil 


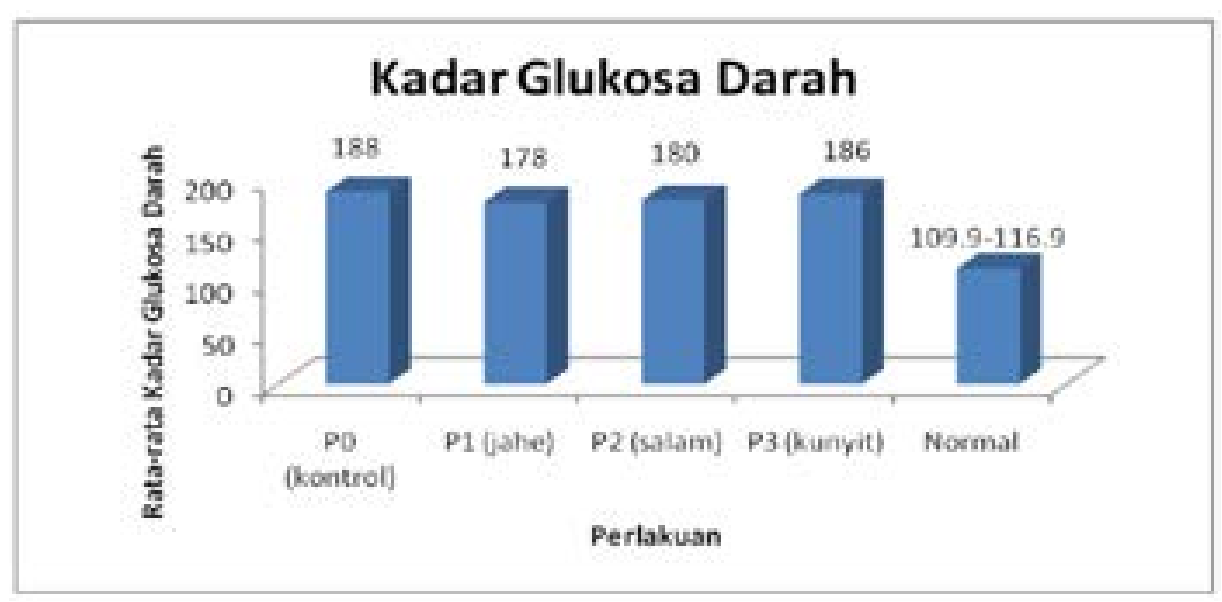

Gambar 2. Histogram Pengaruh Pemberian Tambahan Herbal Jahe, Kunyit dan Salam Terhadap Kadar Glukosa Darah pada Bebek.

yang paling tinggi. Tingginya kadar asam urat pada perlakuan ini disebabkan oleh berbagai faktor salah satunya adalah stress. Asam urat merupakan salah satu gangguan yang terkait dengan kerusakan ginjal pada burung. Penyebab asam urat adalah banyaknya kerusakan ginjal terjadi karena faktor multietiologi yang secara luas dikategorikan sebagai Penyebab nutrisi dan metabolik, penyebab infeksi dan penyebab lainnya seperti mikotoksin (Eldaghayes et al., 2010). Pada saat tubuh (ginjal) gagal memetabolisme protein tinggi dan asupan purin dengan benar hal tersebut yang menyebabkan terjadinya peningkatan asam urat dalam darah (Milind et al., 2013).

Faktor-faktor yang dapat mempengaruhi lainnya disebabkan oleh cekaman stres yang dihadapi oleh bebek tersebut. Cekaman stres tersebut disebabkan oleh faktor lingkungan (suhu udara) maupun faktor lain. Menurut Syukri (2007) stress menyebabkan kadar asam urat dalam serum meningkat. Stress oksidatif yang disebabkan radikal bebas di lingkungan dapat menimbulkan kekacauan dalam sistem pengaturan asam urat dalam tubuh. Hormon stress yang berpengaruh dalam peningkatan kadar asam urat adalah endofrin. Endofrin memiliki pengaruh yang sangat besar terhadap pengaturan respon tubuh terhadap stress. Saat stress tubuh akan mengalami peningkatan metabolisme seluler, glikolisis otot, dan peningkatan produksi hormon antideuritik yang dapat mengurangi produksi urin. Hal ini dapat memicu peningkatan kadar asam urat dalam darah. Meningkatnya hormon endofrin akan mengurangi stress dan menurunkan kadar asam urat dalam darah begitupun sebaliknya penurunan hormon endofrin akan meningkatkan stress dan meningkatnya kadar asam urat darah (Rakhman et al., 2015).

\section{Glukosa Darah}

Hasil penelitian ini rataan kadar asam urat teringgi adalah $188 \mathrm{mg} / \mathrm{dl}$ pada perlakuan kontrol. Sedangkan kadar asam urat terendah adalah $178 \mathrm{mg} / \mathrm{dl}$ pada perlakuan tambahan herbal jahe. Penelitin ini tidak ada pengaruh pemberian tambahan herbal terhadap kadar glukosa darah $(\mathrm{P}>0,05)$.

Kadar glukosa darah pada penelitian ini berkisar 178-188 mg/dL. Menurut Yuwanta et al. (2009) kadar glukosa darah normal pada bebek tegal adalah 116,90 mg/dL. Menurut Sinha (2017) kadar glukosa darah normal pada bebek pati dewasa adalah $109,921 \mathrm{mg} /$ dL. Penelitian ini didapatkan hasil dimana kadar glukosa darah yang melebihi dari normal akan tetapi perolehan kadar glukosa pada perlakuan kontrol didapatkan hasil tertinggi sedangkan pada jahe didapatkan hasil yang terendah. Kandungan jahe mampu mengurangi glukosa plasma dan asam urat. Ekstra jahe secara signifikan menurunkan 
kadar asam urat dengan meningkatkan kandungan insulin dalam tubuh (Saeid et al., 2010). Kadar glukosa darah pada penelitian yang berkisar antara 178-188 mg/dL tersebut memiliki kadar glukosa darah yang melebihi kadar normal pada bebek. Kadar glukosa darah yang melebihi kadar normal pada bebek tersebut disebabkan oleh faktor stress pada bebek. Kondisi lingkungan tidak stabil menyebabkan stress pada bebek.

Stress menyebabkan produksi berlebih pada kortisol, kortisol adalah suatu hormon yang melawan efek insulin dan menyebabkan kadar glukosa darah tinggi. Jika individu mengalami stress berat yang dihasilkan dalam tubuhnya, maka kortisol yang dihasilkan akan semakin banyak, ini akan mengurangi sensifitas tubuh terhadap insulin. Kortisol merupakan musuh dari insulin sehingga membuat glukosa lebih sulit untuk memasuki sel dan meningkatkan glukosa darah (Pratiwi et al., 2014). Konsentrasi glukosa darah yang lebih rendah dapat dikaitkan dengan menurunkan asupan pakan atau aktivitas enzim yang lebih rendah yang terlibat pemecahan karbohidrat (Zhao et al., 2010).

Ternak unggas tergolong hewan homeothermic (berdarah panas) dengan ciri spesifik tidak memiliki kelenjar keringat serta hampir semua bagian tubuhnya tertutup bulu. Kondisi biologis seperti ini menyebabkan ternak unggas dalam kondisi panas mengalami kesulitan membuang panas tubuhnya ke lingkungan. Akibatnya, ternak unggas yang dipelihara di daerah tropis rentan terhadap bahaya stres panas Munculnya stres panas pada ternak unggas dapat menjadi pemicu munculnya berbagai macam penyakit, laju pertumbuhan dan produksi telur menurun dan berakhir dengan turunnya tingkat keuntungan (Tamzil, 2014).

\section{KESIMPULAN}

Hasil penelitian ini menyimpulkan bahwa pemberian berbagai variasi herbal jahe, kunyit, dan daun salam memberikan pengaruh tidak nyata terhadap kadar asam urat dan glukosa darah pada bebek. Stress menjadi salah satu faktor yang memberikan evek tidak nyata pada data. Perlakuan kunyit memiliki kadar asam urat yang paling rendah dengan $4,5 \mathrm{mg} / \mathrm{dL}$ sedangkan pada perlakuan daun salam memiliki kadar tertinggi dengan 7,1 $\mathrm{mg} / \mathrm{dL}$. Glukosa darah pada bebek memiliki kadar terendah pada perlakuan jahe dengan kadar $178 \mathrm{mg} / \mathrm{dL}$, sedangkan kadar tertinggi di peroleh pada perlakuan kontrol dengan kadar $188 \mathrm{mg} / \mathrm{dL}$.

\section{DAFTAR PUSTAKA}

Al-Azzawie, H. F and Samah A.Abd. 2015. Effects of Crude Flavonoids from Ginger (Zingiber officinale), on Serum Uric Acid Levels, Biomarkers of Oxidative Stress and Xanthine Oxidase Activity in Oxonate-Induced Hyperuricemic Rats. International Journal of Advanced Research. Volume 3, Issue 10. 1033 - 1039.

Arum, K. S., V. Bintoro., Priyo danA.N. AlBaarri. 2014. Analisis Mikroboilogi Daging Bebek yang Disimpan dalam Laktoperoksidase System. Jurnal Aplikasi Teknologi Pangan 3 (1), 3740.

Eldaghayes, I. M., M. A. Hamid, S. R. El-Attar. 2010. Pathology Of Gout In Growing Layers Attributed To High Calcium and Protein Diet. E-International Scientific Research Journal. ISSN: 2094-1749 Volume: 2 Issue: 4. 297-302.

Lembong, J. E., Santa, N. M.,Makalew, A. dan Elly, F. H. 2015. Analisis Break Even Point Usaha Ternak Itik Pedaging. Jurnal Zootek ("Zootrek" Journal) Vol. 35 No. $1: 39-45$.

Lina, N dan A. Setiyono. 2014. Analisis kebiasaan makan yang menyebabkan peningkatan kadar asam urat. Jurnal Kesehatan Komunitas Indonesia Vol. 10. No. 2. 1004-1016.

Malkinson, M., M. A. Pitt., M. Dison dan 
E. Bogin. 2007. A Biochemical Investigation of Amyloidosis in The Duck. Avian Pathology. 201-205.

Milind, P ., K. Sushila., S. Neeraj. 2013. Understanding gout beyond doubt. International research journal of pharmacy. ISSN 2230-8407. 25-34.

Pratiwi, P.,G. Amatiria., M. Yamin. 2014. Pengaruh Stress Terhadap Kadar Gula Darah Sewaktu Pada Pasien Diabetes Melitus Yang Menjalani Hemodialisa. Jurnal Kesehatan Volume V Nomor 1. 11-16.

Rakhman, A ., I. Purnawan., A. R. Purwadi. 2015. Pengaruh Terapi Akupresure terhadap Kadar Asam Urat pada Lansia. Jurnal Skolastik Keperawatan. Vol. 1 No. 2. 62-68.

Saeid, J. M., A. B. Mohamed and M. A. ALBaddy. 2010. Effect of aqueous extract of ginger (Zingiber officinale) on blood biochemistry parameters of broiler. International Journal of Poultry Science 9 (10): 944-947.

Setiawan, A. S. 2011. Efek antidiabetes kombinasi ekstrak bawang putih (Allium sativum Linn.) dan rimpang kunyit (Curcumma domestica Val.) dengan pembanding glibenklamid pada penderita Diabetes Melitus Tipe 2. MKB. Volume 43 No. 1. 26-34.

Setyaji, N. I., D. Agustina., I. S. Wardhani. 2016. Efek Kandungan Jahe dalam Menurunkan Kadar Glukosa Darah. Jurnal Keperawatan Madiun Vol. 3 No. 1. 52-58.

Singh, N.,R. C. Ghosh., A.Singh. 2013. Prevalence and Haemato-biochemical Studies on Naturally Occurring Gout in Chhattisgarh. Advances in Animal and
Veterinary Sciences. 1 (3S): $9-11$.

Sinha, S. 2017. Changes in serum biochemical constituents of Pati ducks (Anas platyrhynchos domesticus). The Pharma Innovation Journal 2017; 6(3). 223-225.

Studiawan, H dan M. H. Santosa. 2005. Uji aktivitas penurun kadar glukosa darah ekstrak daun Eugenia polyantha pada mencit yang diinduksi aloksan. Media Kedokteran Hewan. Vol. 21, No. 2. 6265 .

Syukri, M. 2007. Asam Urat dan Hiperuresemia. Majalah Kedokteran Nusantara Volume 40 No. 1. 52-56.

Tamzil, M. H. 2014. Stres Panas pada Unggas: Metabolisme, Akibat dan Upaya Penanggulangannya. WARTAZOA Vol. 24 No 2. 57-66.

Yankusuma, D., P. Putri. 2016. Pengaruh rebusan daun salam terhadap penurunan kadar asam urat di Desa Malanggaten Kecamatan Kebakkramat Kabupaten Karanganyar. JIK. Vol. 4 No. 1. 90-96.

Yuwanta., A. W., Zuprizal., and R. Sutrisna. 2009. Volatile fatty acids and glucose concentration in blood of normal tegal ducks and those underwent caecectomyzed receiving diets of different crude fiber levels. Book of proceeding. 2nd Mediteranian Summit of WPSA.

Zhao, J., Shirley RB., Dibner JD., Uraizee F., Officer M., Kitchell M., VazquezAnon M and Knight CD. 2010. Comparison of hydrated sodium calcium aluminosilicate and yeast cell wall on counteracting aflatoxicosis in broiler chicks. Poultry Science. 89. 2147-2156. 